\title{
Strategies to Resolve Food Insecurity in Guinea International Cooperation Approaches (Availability: Production, Distribution, and Exchange of Food): A Case Study in Guinea
}

\author{
Mamadou Saliou Ly ${ }^{1} \&$ Xuecheng Dou ${ }^{2}$ \\ ${ }^{1}$ College of Finance and Economics, Gansu Agricultural University, Lanzhou, Gansu, P.R. China \\ Correspondence: Xuecheng Dou, Gansu Agricultural University, College of Finance and economics, Anning \\ District, 730070, Lanzhou, Gansu Province, China. Tel: 86-138-9310-1197. E-mail: tigerzyx@163.com
}

Received: August 10, 2020

Accepted: September 15, 2020

Online Published: October 10, 2020

doi:10.5539/ijef.v12n11p59

URL: https://doi.org/10.5539/ijef.v12n11p59

\begin{abstract}
The project at hand addresses the existence of food safety problems in Guinea with the major focus being on the general situation about how it can be recovered using an international approach. The stable food in the nation of Guinea is rice, which is why it's per capita consumption is roughly $100 \mathrm{~kg}$ annually. Guinea's economy relies heavily on agriculture as well as other rural activities and besides that, it is richly endowed with minerals whereby the country has both gold and bauxite reserves. The country's gross domestic product stands at $\$ 10.91$ billion as per the 2018 report of the World Bank. The 2018 World Bank report shows that GDP per capita of Guinea is $\$ 878.60$ with its gross national income being $\$ 30.58$ billion PPP. It for this matter that the paper will cover on the economic situation of the country, its natural resources, the agricultural production, supply and demand, import and distribution, as well as determining the size, importance, and initial judgment of the problem. Additionally, the paper will address past historical practices and problems identified successful experiences of other African countries, and the Chinese experience. It is for this aspect that the government through its relevant bodies should handle the situation using the case of China whereby they have attained food security within the shortest period. The case of Chinese experience is ideal for this paper because they have been in such situations before and thus the reason why the paper focuses on China's development experience based on Guineas agricultural development capacity-building approach research.
\end{abstract}

Keywords: food insecurity, food security, development, government, and collaboration

\section{Introduction}

\subsection{Introduce the Problem}

The major aiding factors include climate change, present, and forecast, as well as weather vagaries because they will influence drastic changes in farming activities. The country is suffering from food insecurity because of inadequate food production, and this has been a trend for a relatively long time (WHO, 2018). Strategies put in place have also not been implemented or embraces, with the most notable one being the rolling out of green revolution, which was proposed and drafted in 2007-2008. Global warming, as well as climate change, have taken center stage in the effects of food insecurity because they affect food production and agriculture. For instance, severe droughts, as well as catastrophic floods, have caused a lot of damages across the nation of Guinea and its agroecosystems and ecosystems (Pautasso et al., 2013). The issue of food availability and food security in Guinea depends on the combination of food importations and local production, which is ideal for both the regional stature as well as international markets.

\subsection{Explore the Importance of the Problem}

The FAO report (2018) by the United Nations' FAO (Food and Agriculture Organization) shows that food insecurity remains to be a major concern globally because more than 1 billion people are still suffering from malnutrition and starvation. This, therefore, means that the world is yet to attain its MDG (millennium development goal), which was supposed to have clocked half a billion by the end of 2015 in terms of poverty and hunger. The nations within sub-Saharan Africa have registered a high number of people who are suffering due to food insecurity, with more than 239 million people still under starvation (FAO report, 2018). The nation of Guinea is not behind in this matter as they are also facing the challenge of food insecurity in terms of insufficient food 
production, low food intake, unavailability of food, poor food quality as well as foods with poor nutritional value. The direness of the situation is manifested in women and children who remain to be the most vulnerable people in society.

The nation has been registering escalating food riots and food prices due to prevailing food insecurity and food crisis. It is for this case that the government through its relevant bodies should handle the situation using the case of China whereby they have attained food security within the shortest period. With a population of 13.3 million, an unemployment rate of $3.6 \%$, and the inflation (CPI) of $9.7 \%$, the country stands a better chance of positive trajectory growth. Farmers also need to be trained on the issues of agriculture because whereas others are misusing fertilizers, others are underusing or not using them at all hence affecting the production of their farms.

\section{Methodology}

\subsection{Data Source}

There are different ways in which a researcher can undertake their research to make it successful and ideal for future reference. The investigation at hand will focus on the possible solutions that the government of Guinea and related bodies can use in addressing the issue of food security. To deal with this research, it will be ideal to use case study methodology to analyze the situations of the country as well as other nations that have been to a similar situation. The use of a case study in research falls under descriptive research.

The data collection approach used includes observation and participation as well as examining existing records, tests, and interviews (Kumar, 2019). Using this research approach is appropriate as it helps in describing and exploring aspects of the flood situation in both Guinea-Conakry and the rest of the world. The use of a case study is also ideal in data and information collection because it will help in creating a deeper comparison between the target countries. The consistency of the outcome will also be a factor as it will help in understanding the degree of the matters at hand. The search results and information collected from these sources should have some similarities which makes it ideal to use them in concluding. For the data collected to meet the criteria required, it will be necessary to ensure that the data used to meet the minimum research threshold. For instance, the data and information collected at several websites should have similar information and outcome with those that are collected at Springer Link. Uniformity of the research outcome is necessary as they will help in attaining a better understanding of the subject matter.

\subsection{Objectives}

The primary aim of this paper is to answer the following crucial inquiries:

1) What is the current food situation in Guinea-Conakry?

2) Can the government of Guinea learn from the past and tackle the issue of food insecurity?

3) How is the food situation in Africa?

4) Can the government of Guinea use the Chinese approach in solving its food insecurity

\section{Results}

\subsection{Economic Situation}

Guinea's economy relies heavily on agriculture as well as other rural activities and besides that, it is richly endowed with minerals whereby the country has both gold and bauxite reserves. The country's gross domestic product stands at $\$ 10.91$ billion as per the 2018 report of the World Bank. The 2018 World Bank report shows that GDP per capita of Guinea is 878.60 USD with its gross national income being 30.58 billion PPP dollars. The country has potential agricultural production, but its domestic production has not sufficed the market demand, and that is why the country is currently importing more than $25 \%$ of its staple food requirements. Despite the market monitoring activity, which is handled by various organizations, both private and government entities, there is still the issue of limited information flows and coordination. The results here are the poor analysis of the performance of products in the market as well as lack of continuous and complete price data series. Despite being rich in terms of natural resources, the nation of Guinea still faces a significant amount of socio-economic challenges, with the most notable one being its poverty index. The nation has roughly $21.8 \%$ of households living under a food-insecure state with malnutrition being high (Onifade, Aduradola, \& Adamu, 2016). The most vulnerable part of this country that is affected by food deficiency and food insecurity is the rural populations who are reported to be $71.1 \%$, subsistence farmers.

\subsection{Agricultural Production}

The stable food in the nation of Guinea is rice, which is why it's per capita consumption is roughly $100 \mathrm{~kg}$ annually. 
The second stable food in guinea is cassava, which is also imported to meet the demands of the nation. There has, however, been the increase in maize consumption over the years as a substitute for rice (Balde et al., 2014). Other crops include groundnuts, Irish potatoes, as well as a variety of vegetables such as tomatoes, eggplant, peppers, okra, and cabbage. Despite all this volume of foodstuffs, the nation of Guinea is still faced with the challenge of food insecurity, and this paper will cover ways to solve food security in Guinea international cooperation approaches. The poverty index goes hand in hand with food insecurity, with the most notable part being that the said population is mostly smallholder farmers (Lu et al., 2015). Additionally, the challenge has been attributed to the poor access to fertilizers and seeds, processing and production equipment, basic infrastructure, storage facilities, as well as affordable financial services. According to Camara et al. (2011), women are also being affected by this issue because despite having a role to play such as taking part in agriculture as a way of being part of food production, the society and culture do not allow them access to land. They are also restricted from aspects such as productive resources, income-generating activities, education, as well as formal employment (Camara et al., 2011). The nation of Conakry Guinea has been marred by recurring natural disasters, notably bush fires and flooding, which directly affect food-insecure people.

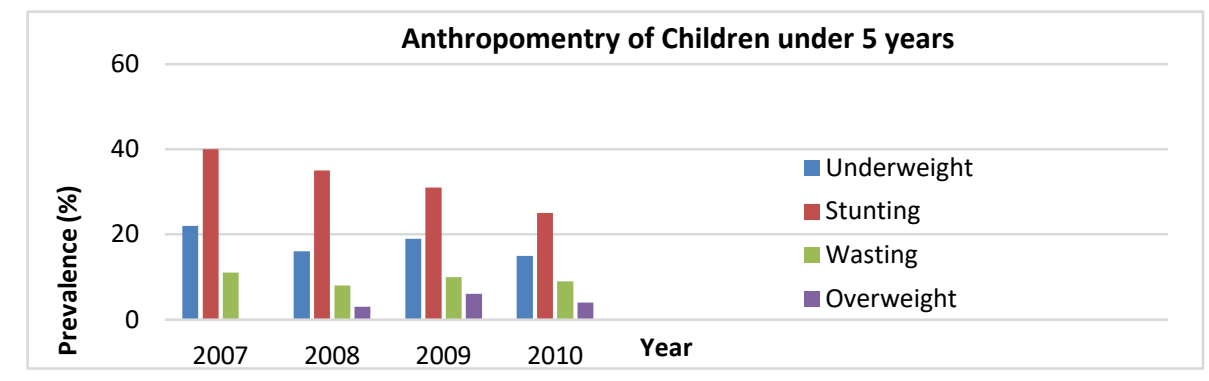

Figure 1. Malnutrition in children (WHO 2015)

\subsection{Food Security Regarding Supply and Demand}

Proper use of fertilizers will help in boosting the productivity of the farms hence making it possible for the farmers to increase their input effort into the country food cycle. The main entities in the course of training farmers on the use of fertilizers include timing adjustments, type, and placement of fertilizers (Onifade, Aduradola, \& Adamu, 2016). It, therefore, means that the farmers will not be incurring losses through ignorance, such as using the wrong type of fertilizers of using them during the wrong time. The continuous rise in the population also means that there will be food insecurity due to inadequate food supply. According to Raghav and Shantanu (2018), the demand for food will rise with the rise in the population, which implies that there will be a need to increase food production to curb this situation. There is a need for the government to also curb the population increase through educations such as family planning and controlled population. Those living in rural areas are still naïve with such things, and as such, they give birth to more children than they can feed. High population means that there will be high food demands, which will consequently lead to an increase in the possibility of food insecurity (Raghav \& Shantanu, 2018). The government, through relevant ministries, should plan on how it can create equilibrium in this situation by putting in place mechanisms that will help in increasing food supply.

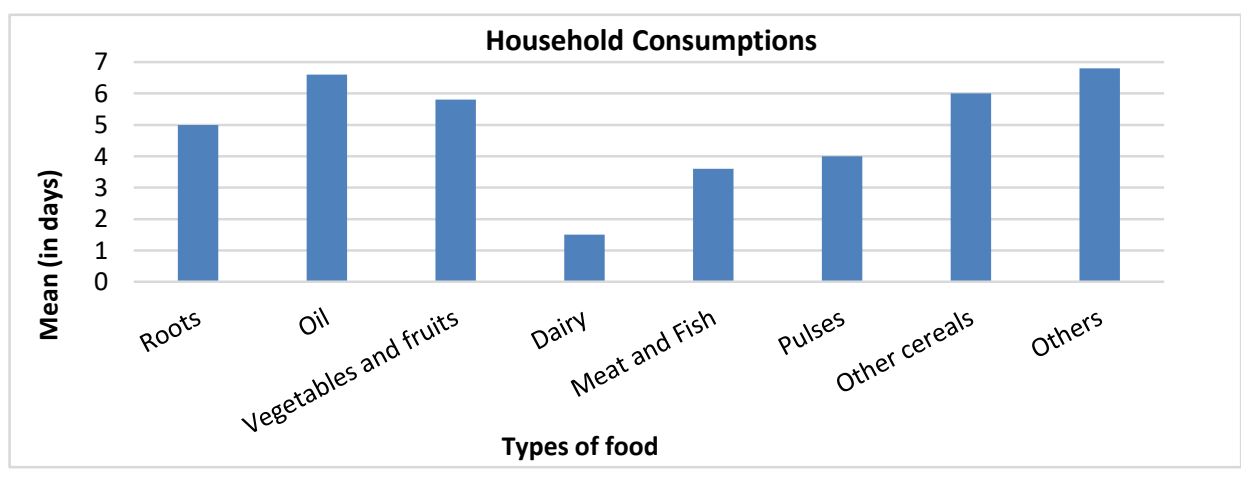

Figure 2. Type of food against household consumption 


\subsection{Import and Distribution}

According to Aker (2008), farmers in Guinea have been suffering because of the high level of imported foods and foodstuffs. The irony part of this case is that the products being imported are the same products that can be grown in the country. If these importations continue, the farmers will end up ditching farming and farming activities, and that is how the food insecurity will hit. The nation will now suffer because the farmers will no longer be willing to produce foods due to inflated prices (Adhikari, 2016). Once the food demands go high, the smugglers and other food importers will raise the prices of these commodities hence making it hard for the consumers to purchase them. Among the most notable ways of improving food production is land consolidation. This means that the government should start consolidating lands and moving people out of densely populated areas, which are rich agricultural lands to urban areas with the least agricultural value.

Table 1. Current studies on food security

\begin{tabular}{llll}
\hline \multicolumn{2}{l}{ Primary issues } & Source/ Digital Library & Authors \\
\hline - & Food security in China & Google Scholar & (Zhang et al., 2012), (Lu et al., 2015) \\
- & The food situation in Africa & SpringerLink & (Fan et al., 2012), (Koizumi, 2013) \\
- & Agricultural production & Wiley Online & (Luan, Cui, \& Ferrat, 2013) \\
- $\quad$ Role of women in food security & Emerald & (Adhikari, 2016) \\
- $\quad$ Import and distribution in Guinea & JSTOR & (Abdenur \& de Souza Neto, 2013) \\
& & & (Raghav \& Shantanu, 2018) \\
& & & (Pautasso et al., 2013) \\
& & (Camara et al., 2011) \\
& & (Onifade, Aduradola, \& Adamu, 2016) \\
\hline
\end{tabular}

\section{Discussion}

\subsection{Determine the Size, Importance, and Initial Judgment of the Problem}

Even though the nation has had past fiscal mismanagement, they do have in place long-term economic prognosis which remains promising for this nation as it has strong natural resources endowments, arable land, reliable rainfall, as well as energy opportunities. The country has been working with foreign nations to stimulate its growth with the most notable one being China who has invested heavily in this country. The major concern of this country is the lack of political stability which has affected the business confidence of the nation. According to Kang et al. (2017), it is clear that the export earnings of this country from sources such as extractive industries have fallen short of generating neither broad-based economic activity nor the domestic market development. The country is still limited when it comes to crucial entities such as corruption and improvement in the rule of law.

Modernized agriculture has been made a strategic priority in Guinea but there have been complaints that the effort put is insufficient. There is also a huge wealth gap when rural and urban areas are compared that is job opportunities are less at the rural causing economic instability in the country (Adhikari, 2016). The outbreak of the Ebola virus disease outbreak (EVD) in 2014 in the nation of Guinea affected 76.6\% of children between 6 and 59 months as they became anemic, whereas $31.2 \%$ became stunted (Carroll et al., 2015). The situation means that the nutrition level in the country was driven further downwards hence attracting the attention of USAID/Washington and USAID/Guinea, who intervened to help in fighting Ebola (Carroll et al., 2015). The Bureau for Food Security (BFS) of both USAID/Washington and USAID/Guinea joined forces in pressurizing SPRING to carry out nutrition assessment within the population to help in identifying key elements that contributed to the undernutrition. The move was also meant to quantify the effects that Ebola had on the behavioral and social constraints within the population.

\subsection{Past Historical Practices and Problems Identified}

The past mistakes and problems when it comes to handling agriculture, related ministries as well as the commitment from the head of state has been primary challenges causing food insecurity in this country. The relevant ministries have not done much in the past in ensuring that the nation of Guinea has attained a better food security stature. There is also doubt and concerns over better policies guiding agriculture and food handling. Although the country is putting effort to ensure that the size of arable land is maintained at the size mentioned above there are some challenges that threaten the number and these include creeping desert sands, development in the urban regions, and pollution of soil (Abdenur \& de Souza Neto, 2013). The move will help in attaining sustainable and higher-yielding agriculture. Corn ears that have been harvested are piled on open grounds and 
roads as observed by Abdenur and de Souza Neto (2013). Furthermore, a large quantity of the grain is destroyed by pests, adverse weather conditions, and molds hence the loss of the grain. The relevant ministries of Guinea have failed in the past to borrow approaches used for success by nations such as China as a way of embracing good practices that will cover the social as well as economic measures and political will as observed by Kang et al. (2017). Guinea as well as rural communities failed in the past to use mechanisms such as protecting them against unnecessary and unfair competition, preventing cheap agrifood products that come from overseas into the local market as well as unfair trade (Wei et al., 2015). These measures and aids from the international community will help the country in handling the issue of food insecurity.

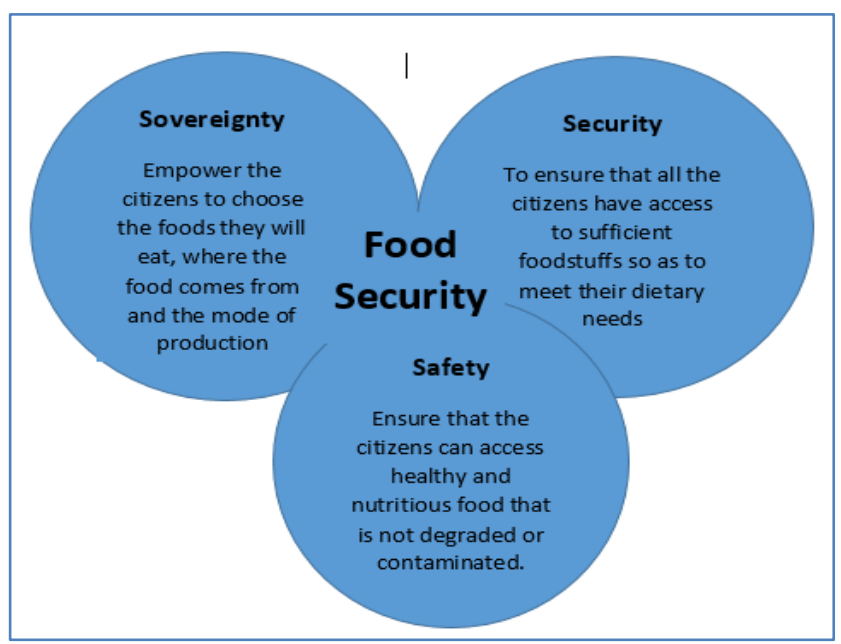

Figure 3. Food Security Triangle (Senahoun et al., 2014)

\subsection{Successful Experiences of Other African Countries}

The green revolution has been deployed in nations such as South Africa with the aid of proper planning and comprehensive policies. According to Vasconcellos and Sobrinho (2015), the government, through relevant ministries in South Africa, assumes the responsibility of working with international donors to bring about the fulfillment of food security within the country and the communities. The international communities and donors in most African countries have been of importance because they will help the local farmers in practicing appropriate agriculture. Furthermore, countries such as Kenya through relevant ministries rolled out measures to handle the products as a way of mitigating potential risks. The approach was used by the Kenyan government to address the wastage of foods. The U.N Food and Agricultural Organization has given reports that food that goes at a waste worldwide amounts to a third (Luan, Cui, \& Ferrat, 2013). Gale said that a campaign that aims at storage facility improvement and providence of bins subsidies has been launched by the government. There is also a role that is being played by culture. The country of Morocco ensured that influenced its residents against a culture of serving lavish meals to reduce the wastage in food expenditures (Luan, Cui, \& Ferrat, 2013). Despite the market monitoring activity, which is handled by various organizations, both private and government entities, there is still the issue of limited information flows and coordination.

\subsection{The Chinese Experience}

The ability of China, on the other hand, to manage to provide food to its residents has been considered a considerable step to ever happen to owe to the fact that 30 million of its population succumbed to death due to hunger half a century ago (Koizumi, 2013). The strategies put into place in China to ensure that there is a secure and safe supply of food as the country constantly continues to enlarge will have global ramifications. It is because of this aspect that the paper uses the situation of China as a framework that they can use to solve the issue of food security. China, as a country, managed to produce a sufficient amount of corn considering the size of the population at the moment. According to Koizumi (2013), the current situation presents a situation whereby the supply might fall short in terms of meeting the demand in the coming future by livestock being kept in the country. According to the government of China, the country's size of arable land should not be below 297 million acres.

China has very small plots that range from half an acre to two whereby a single field can be shared by quite several households. This brings about the difficulty in planning for farming due to inefficiency, therefore, 
making it impossible for the farmer to depend on farming only as a means of earning income. To enhance profits and efficiency farmers have to work at their farms despite the sizes as they earn money on little plots for example on an 8-acre plot and still manage to save at the end of the day ( $\mathrm{Lu}$ et al., 2015). This study was done by a USDA economist called Fred Gale. The country is experimenting with quite some business models such as cooperatives.

\section{Conclusion and Recommendation}

The issue of food security should be handled by the government through its relevant ministries. The ministries who should be handling this matter should be a combination of the ministry of agriculture, ministry of economy $\&$ finance, ministry of energy \& water, ministry of national education \& scientific research, and the ministry of planning. Radical and aggressive measures will help in stabilizing food situations because it will increase the production of foods, which translates to improved food security. Food production should also go hand in hand with food availability. Researchers will have to help the government is working on other means, such as identifying areas that are best fit for particular crops as well as the timing of farming. It is possible to attain food security in a nation, but it is a demanding affair, and as such, there is a need to embrace combined efforts between the government and the private sector. The strategy will help the nation of Guinea to attain better food security.

\subsection{Recommendation}

The study highly recommends that:

The leaders should encourage "family farm" which is just but a term that was first heard of some two years ago in the national lexicon. This initiative is all about individual families carry out farming by running operations that are of large sizes and from that can get incentives, subsidies, and earn a large portion of their income utilizing farming. The nation of Guinea should, therefore, use this approach in ensuring that despite having small plots, they can still make them profitable.

The government should intervene on matters of importation by increasing the taxation on imported goods. The increase in the country's dependence on imported foods has contributed heavily to the increase in food insecurity due to its high prices as well as high price volatility. The approach of increasing the tax on imported goods should force the locals to work towards improving their food granaries.

The identification and analysis of all the aspects of food security and importation of foods will help in increasing the chances of containing food security within the nation. The country should, therefore, deploy a proper stimulus plan that will help the country in mitigating risks such as epidemics and food shortages in case the taxation on imported goods will not work as planned.

\section{Acknowledgments}

Team members would like to extend their heartfelt gratitude to the ministry of agriculture and the ministry of national education \& scientific research for their efforts and contribution towards the completion of this paper. We also appreciate the Alusa Complex, a statistical team, for their help with appropriate statistics and data that helped in completing this paper. We also appreciate the efforts of our able supervisor/professor and Mr. James Blackar Mawolo who helped use throughout writing this paper. To all the team and critics who went through this paper, we highly appreciate the comments and suggestions.

\section{References}

Abdenur, A. E., \& de Souza Neto, D. M. (2013). South- South cooperation and democracy in Africa: Brazil's role in Guinea-Bissau. Africa Review, 5(2), 104-117. https://doi.org/10.1080/09744053.2013.855356

Adhikari, P. (2016). Mapping and Analyzing Urban Growth: A Study to Identify Drivers of Urban Growth in West Africa. https://doi.org/10.1080/1747423X.2017.128055.0

Balde, B. S., Kobayashi, H., Nohmi, M., Esham, A. I. M., \& Tolno, E. (2014). An analysis of the technical efficiency of mangrove rice production in the Guinean Coastal Area. Journal of Agricultural Science, 6(8), 179. https://doi.org/10.5539/jas.v6n8p179.

Camara, M., Wen, Y., Wu, H., Diakite, M., Gerson, K. K., \& Wang, H. (2011). Impact assessment of women farmer activity on poverty reduction and food security: a case of the Kindia region/Guinea. Journal of Agricultural Science, 3(4), 141. https://doi.org/10.5539/jas.v3n4p141.

Carroll, M. W., Matthews, D. A., Hiscox, J. A., Elmore, M. J., Pollakis, G., Rambaut, A., \& Abdellati, S. (2015). Temporal and spatial analysis of the 2014-2015 Ebola virus outbreak in West Africa. Nature, 524(7563), 
97-101. https://doi.org/10.1038/nature14594.

Fan, M., Shen, J., Yuan, L., Jiang, R., Chen, X., Davies, W. J., \& Zhang, F. (2012). Improving crop productivity and resource use efficiency to ensure food security and environmental quality in China. Journal of Experimental Botany, 63(1), 13-24. https://doi.org/10.1093/jxb/err248

Kang, S., Hao, X., Du, T., Tong, L., Su, X., Lu, H., \& Ding, R. (2017). Improving agricultural water productivity to ensure food security in China under a changing environment: From research to practice. Agricultural Water Management, 179, 5-17. https://doi.org/10.1016/j.agwat.2016.05.007

Koizumi, T. (2013). Biofuel and food security in China and Japan. Renewable and Sustainable Energy Reviews, 21 , 102-109. https://doi.org/10.1016/j.rser.2012.12.047.

Lu, Y., Jenkins, A., Ferrier, R. C., Bailey, M., Gordon, I. J., Song, S., \& Feng, Z. (2015). Addressing China’s grand challenge of achieving food security while ensuring environmental sustainability. Science advances, 1(1), e1400039. https://doi.org/10.1126/sciadv.1400039

Luan, Y., Cui, X., \& Ferrat, M. (2013). Historical trends of food self-sufficiency in Africa. Food Security, 5(3), 393-405. https://doi.org/10.1007/s12571-013-0260-1

Onifade, C. A., Aduradola, R. R., \& Adamu, C. O. (2016). The Culture of Violence against Women and Its Impact on Sustainable Food Security in Nigeria. Journal of Education, Society and Behavioural Science, 1-12. https://doi.org/10.9734/BJESBS/2016/24010

Pautasso, M., Aistara, G., Barnaud, A., Caillon, S., Clouvel, P., Coomes, O. T., \& Eloy, L. (2013). Seed exchange networks for agrobiodiversity conservation. A review. Agronomy for Sustainable Development, 33(1), 151-175. https://doi.org/10.1007/s13593-012-0089-6

Raghav, G., \& Shantanu, M. (2018). Agricultural research, technology, and nutrition in Sub-Saharan Africa. Hunger and Malnutrition as Major Challenges of the 21st Century, 3, 291. https://doi.org/10.1142/9789813239913_0010.

Senahoun, J., Gunjal, K., Mwanundu, R., Sandstrom, S., \& Giuffrida, V. (2014). FAO/WFP crop and food security assessment - Guinea. Special Report, 21(3), 6-30. https://doi.org/10.1016/0306-9192(96)81816-1

Wei, X., Zhang, Z., Shi, P., Wang, P., Chen, Y., Song, X., \& Tao, F. (2015). Is yield increase sufficient to achieve food security in China? PloS one, 10(2). https://doi.org/10.1371/journal.pone.0116430

Zhang, F., Cui, Z., Chen, X., Ju, X., Shen, J., Chen, Q., \& Jiang, R. (2012). Integrated nutrient management for food security and environmental quality in China. In Advances in agronomy (Vol. 116, pp. 1-40). Academic Press. https://doi.org/10.1016/B978-0-12-394277-7.00001-4

\section{Copyrights}

Copyright for this article is retained by the author(s), with first publication rights granted to the journal.

This is an open-access article distributed under the terms and conditions of the Creative Commons Attribution license (http://creativecommons.org/licenses/by/4.0/). 